\title{
ANALYSIS OF SPRING WATERS FROM LESKO IN TERMS OF THEIR MEDICAL PROPERTIES
}

\author{
Artur Chorostyński ${ }^{1 凶}$, Mateusz Kaczmarski², Andrzej Łach³, Marcin Wrona² \\ ${ }^{1}$ Department of Food Chemistry and Toxicology, Rzeszow University, ul. Ćwiklińskiej 1 A, 35-601 Rzeszów \\ ${ }^{2}$ Faculty of Agriculture and Forest Ecosystems Management, The Jan Grodek State University in Sanok, ul. Mickiewicza 21, \\ 38-500 Sanok \\ ${ }^{3}$ School Complex Nr 2 in Sanok (retired employee), ul. Stróżowska 15, 38-500 Sanok
}

\begin{abstract}
Aim of the study

The aim of the study was to demonstrate the medical properties of spring waters from Lesko based on their physicochemical analysis.

Material and methods

There are three active sulphide springs and one mineral spring in Lesko. In water samples from Lesko $(1,2,3)$ sulphides and hydrogen sulphide (divalent sulphur) were determined. The sulphide and hydrogen sulphide concentration in the springs was determined with iodometric, photometric and thiomercurimetric methods. All samples were checked for the presence of 7 heavy metals with the AAS method. In all examined waters, an additional quantitative analysis of such components as metaboric acid, orthosilicic acid, sulphur, bromine, iodine was carried out with two methods: the ICP-MS and the ICP-OES. Also, fluorine content was determined with ion chromatography.
\end{abstract}

\begin{abstract}
Results and conclusions
All waters from Lesko, except mineral water, contain sulphides. No heavy metals, including mercury and arsenic, were detected in all spring waters. No lithium or significant amount of iron and manganese were found. In the waters $(1,2,3)$ no selenium and molybdenum were found. In the examined waters $(1,2,3,4)$, metaboric acid, orthosilicic acid, fluorine and iodides were found
\end{abstract}

Keywords: ICP-OES, balneology, Lesko, sulphide springs, ORP

\section{INTRODUCTION}

There are numerous springs of sulphide waters in the entire Carpathian Mountains, including in Poland (Rajchel, 2000). They contain hydrogen sulphide quantities from 1 to $160 \mathrm{mg} \cdot \mathrm{dm}^{-3}$, with mineralisation of 0.3 to $3.6 \mathrm{~g} \cdot \mathrm{dm}^{-3}$ but usually not exceeding $1 \mathrm{~g} \cdot \mathrm{dm}^{-3}$. Three springs contain carbon dioxide, while in more than twenty springs metaboric acid $\left(\mathrm{HBO}_{2}\right)$ was found with a concentration above $5 \mathrm{mg} \cdot \mathrm{dm}^{-3}$ (Paczyński and Sadurski, 2007). The origin of hydrogen sulphide is commonly associated with pyrite dispersed in rocks (Rajchel et al., 2005). However, the preliminary isotope studies do not exclude that the gas could originate from the Earth's mantle in several cases (Rajchel et al., 2002). Springs of sulphide waters have characteristic sediments, consisting of various colonies of sulphur bacteria (Rajchel et al., 2000) and white sediment of

巴e-mail: cholapa@onet.pl 
elemental sulphur. Naturally, sulphur occurs in reduced form as hydrogen sulphide $\left(\mathrm{H}_{2} \mathrm{~S}\right)$ and sulphides $\left(\mathrm{HS}^{-}, \mathrm{S}^{2-}\right)$, in molecular form $\left(\mathrm{S}^{\circ}\right)$ and in oxidised form as sulphates (VI) $\left(\mathrm{SO}_{4}^{2-}\right)$ (Paluch, 1973). In other forms of oxidation, it can occur only temporarily as stages of oxidation-reduction reactions (sulphur biogeochemical cycle) (Paluch, 1973). In the Carpathian province that covers the external Carpathian region, sulphide waters occur in the town of Wapienne (Paczyński and Sadurski, 2007). In this town, sulphide waters and mud are the basic medical raw materials (Tchórzewska-Cieślak and Rak, 2006). Wapienne near Gorlice is the smallest and the only Carpathian health resort with healing sulphide waters (Chowaniec et al., 2013).

The place where the sulphide springs are located is the town of Lesko ( $\mathrm{Kach}, 2005$; Kozak, 2016). The town has a rich tradition associated with the healing properties of several sulphide and mineral springs. The basic components of mineral waters that determine its degree of mineralisation include: chloride, bicarbonate and sulphate (VI) anions; as well as sodium, potassium, calcium and magnesium cations. This qualification is complemented by the introduction of specific ingredients which are chemical elements or compounds with a proven therapeutic effect (Tchórzewska-Cieślak and Rak, 2005). Waters in Lesko springs are $\mathrm{HCO}_{3}-\mathrm{Ca}-(\mathrm{Mg}), \mathrm{H}_{2} \mathrm{~S}$ type waters in which hydrogen sulphide is the specific component. The resources of the above mentioned waters were estimated at $0.2 \mathrm{~m}^{3} \cdot \mathrm{h}^{-1}$ (Paczyński and Sadurski, 2007). The aim of the study was to demonstrate the healing properties of spring waters from Lesko.

\section{MATERIAL AND METHODS}

\section{Area of research}

Lesko is a town located on the San river in south-eastern Poland, in the Podkarpackie Voivodeship (see: Fig. 1). Already before World War I, there was a spa at the present Źródlana street, and in the inter-war period, a natural medical institution was located there (Kozak, 2016). The springs, mostly hydrogen sulphide, were rebuilt in the form of reinforced wells and covered with concrete slabs (see: Fig. 2). The wells were only 2 meters deep. In 1936, a water pump room was established and it was planned to build bathrooms. The Voivodeship Office in Lviv oversaw the development of the spa, which in the future was to become a new resort in the Polish Carpathians.

To the south-east of Lesko, signs of arsenic-mercury mineralisation were found. Arsenic mineralisation occurs in the Central Carpathians. Anomalous concentrations of mercury and arsenic were detected in the weathering zone of flysch sediments near Baligród (Bystre, Rabe) (Jaworski, 1979). Arsenic-mercury mineralisation also applies to Lesko, and it was noticed before World War II (Kamieński, 1937). Today, arsenic has been found in groundwater in the Rabe 1 bore in the town of Rabe (Łach and Pasztyła, 2013; Chorostyński et al., 2016).

\section{Methodology}

There are 4 springs in Lesko, and their geographical coordinates (see: Table 1) and altitude were determined. Sulphide springs were marked with $(1,2,3)$, and mineral spring that does not contain hydrogen sulphide with (4). For comparison, the Jan sulphide spring (5) in the spa town of Rymanów Zdrój in the Jasło-Ustrzyki sub region was included (Paczyński and Sadurski, 2007). The water analysis from this spring was performed by the Szczawna-Zdrój Balneoprojekt laboratory (Jaworski and Uliasz, 2006), and by the authors of the study.

Measurements and analyses of all parameters of water samples taken in spring, summer and autumn were carried out in accredited research laboratories or independently using applicable Polish standards, methodologies or validated testing procedures based on them. The measuring equipment used in the field was calibrated before measurements on the day of their performance.

For spring waters $(2,3,4,5)$ physicochemical measurements (see: Table 2 ) of following parameters were carried out: $\mathrm{pH}$, oxidation-reduction potential (ORP), conductivity and temperature.

In water samples from Lesko $(1,2,3)$ with a characteristic smell of "rotten eggs", sulphides and hydrogen sulphide were determined. In the water from the spring (1), sulphides were determined using the iodometric method at first (Chorostyński et al., 2018). Now more accurate thiomercurimetric determining was performed in an accredited research laboratory using $\mathrm{PN}-82 / \mathrm{C}-04566.03$. Determining of sulphides in the spring (2) was carried out based on the Mache- 


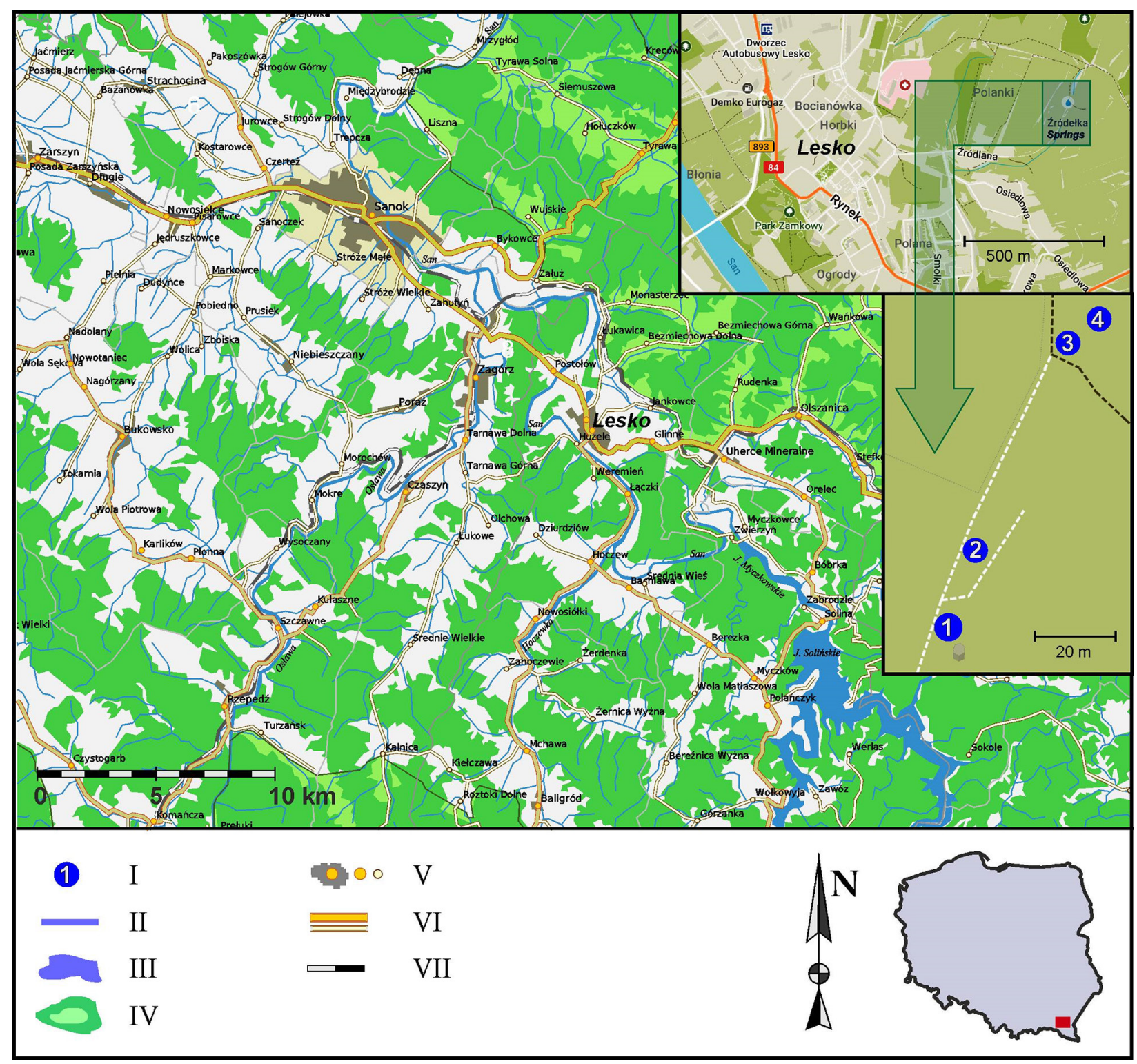

Fig. 1. Location of springs in Lesko, I - spring number; II - rivers, streams; III - lakes, water reservoirs; IV - forests; V - cities, towns; VI - national, local roads; VII - railway lines

Source: Author's own studies based on cartographic materials supplied by the State Forests and GPS MAPS.ME offline maps

rey-Nagel TEST in an accredited environmental testing laboratory. Sulphides and hydrogen sulphide in the spring (3) were determined iodometrically according to the method given by Minczewski and Marczenko (Minczewski and Marczenko, 2011). The Lesko spring (4) is a mineral spring free of sulphides and hydrogen sulphide (no characteristic odour and taste - the sensitivity of the organoleptic method is comparable to that of instrumental methods). The concentration of hydrogen sulphide (see: Table 2) in the Jan water in Rymanów Zdrój - water (5) was based on literature (Jaworski and Uliasz, 2006). 
Chorostyński, A., Kaczmarski, M., Łach, A., Wrona M. (2019). Analysis of spring waters from Lesko in terms of their medical properties. Acta Sci. Pol., Formatio Circumiectus, 18 (3), 31-41. DOI: http://dx.doi.org/10.15576/ASP.FC/2019.18.3.31
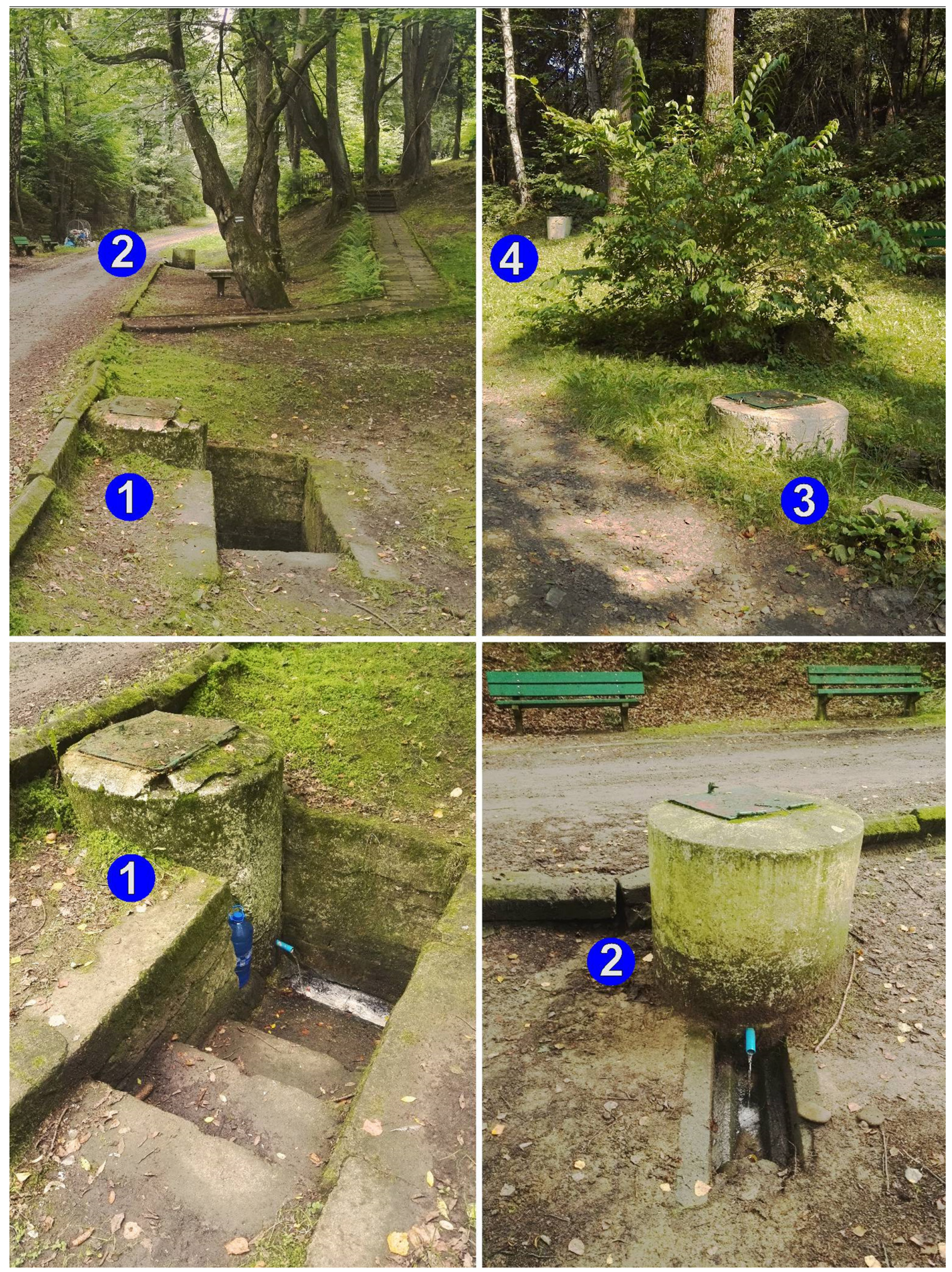

Fig. 2. View of enclosed springs in Lesko: 1, 2, 3, 4-wells with spring water (photos taken by the authors) 
Chorostyński, A., Kaczmarski, M., Łach, A., Wrona M. (2019). Analysis of spring waters from Lesko in terms of their medical properties. Acta Sci. Pol., Formatio Circumiectus, 18 (3), 31-41. DOI: http://dx.doi.org/10.15576/ASP.FC/2019.18.3.31

Table 1. Location of tested springs

\begin{tabular}{cccccccc}
\hline Parameter & Spring & $\begin{array}{c}\text { Spring and } \\
\text { sample } \\
\text { code }\end{array}$ & GPS N & GPS E & $\begin{array}{c}\text { Position } \\
\text { m a.s.l. }\end{array}$ & Scent type & Water type \\
\hline LESKO & LE & 1 & $49^{\circ} 28,380^{\prime}$ & $22^{\circ} 20,554^{\prime}$ & 373 & "rotten eggs" & sulphide \\
\hline LESKO & LK & 2 & $49^{\circ} 28,378^{\prime}$ & $22^{\circ} 20,550^{\prime}$ & 382 & "rotten eggs" & sulphide \\
\hline LESKO & LO & 3 & $49^{\circ} 28,403^{\prime}$ & $22^{\circ} 20,570^{\prime}$ & 387 & "rotten eggs" & sulphide \\
\hline LESKO & CM & 4 & $49^{\circ} 28,416^{\prime}$ & $22^{\circ} 20,586^{\prime}$ & 390 & no scent & mineral \\
\hline $\begin{array}{c}\text { Rymanów Zdrój } \\
\text { health resort }\end{array}$ & $\mathrm{X}$ & 5 & $49^{\circ} 32,890^{\prime}$ & $21^{\circ} 51,160^{\prime}$ & 156 & "rotten eggs" & sulphide \\
\hline
\end{tabular}

Table 2. Concentration of sulphides as well as physical and bacteriological properties of water

\begin{tabular}{|c|c|c|c|c|c|c|c|c|c|}
\hline $\begin{array}{l}\text { PARAMETER } \\
\text { SAMPLE }\end{array}$ & Sulphides & $\mathrm{pH}$ & Redox & $\begin{array}{l}\text { Condu- } \\
\text { ctivity }\end{array}$ & $\begin{array}{l}\text { Tempera- } \\
\text { ture } \\
\mathrm{T}\end{array}$ & $\begin{array}{l}\text { Coliform } \\
\text { bacteria }\end{array}$ & $\begin{array}{l}\text { Escherichia } \\
\text { Coli }\end{array}$ & $\begin{array}{c}\text { Faecal } \\
\text { enterococci }\end{array}$ & $\begin{array}{c}\text { Water } \\
\text { suitable for } \\
\text { consumption } \\
\text { according }\end{array}$ \\
\hline UNIT & $\mathrm{mg} \cdot \mathrm{dm}^{-3}$ & unitless & $\mathrm{mV}$ & $\mu \mathrm{s} \cdot \mathrm{cm}^{-1}$ & ${ }^{\circ} \mathrm{C}$ & \multicolumn{3}{|c|}{ units $\cdot 100 \mathrm{~g} \mathrm{~cm}^{-3}$ of water } & $\begin{array}{l}\text { to the Decree } \\
\text { from } 2010\end{array}$ \\
\hline 1 & 1.90 & 7.70 & -230 & 540 & 9 & 0 & 0 & 0 & Yes \\
\hline 2 & 0.10 & 7.30 & -90 & 520 & 13 & 0 & 0 & 0 & Yes \\
\hline 3 & 0.80 & 7.60 & -180 & 600 & 12 & 0 & 0 & 0 & Yes \\
\hline 4 & $\begin{array}{c}\text { no } \\
\text { sulphides }\end{array}$ & 6.90 & +145 & 720 & 13 & not tested & not tested & not tested & No data \\
\hline 5 & 1.40 & 7.20 & +80 & 2340 & 16 & 0 & 0 & 0 & Yes \\
\hline
\end{tabular}

Arsenic-mercury mineralisation around Lesko may be the reason for underground water enrichment with heavy metal ions as a result of water infiltration by rocks with increased mineralisation resulting from the presence of chemical compounds of these metals. Therefore, in all water samples, atomic absorption spectrometry (ASA) analysis of heavy metals: zinc, cadmium, copper, lead, nickel, chromium, mercury (see: Table 3), and arsenic (see: Table 4) (toxic and carcinogenic elements) (National Research Council, 2001; ATSDR, 2007, Dobrzyński i Stępień, 2009) was performed. Water samples were also analysed with this method for the presence of micronutrients: lithium, manganese, iron (see: Table 4) and for sodium, potassium, calcium and magnesium content (see: Table 5).

In the water samples, carbon dioxide content and concentration of anions: bicarbonates (acid-base ti- tration), chlorides (argentometry), and sulphates (VI) (turbidimetry) were examined (see: Table 6). In the sulphide waters $(1,2,3)$ in which sulphides were detected and determined, bacteriological determinations were carried out, including: Escherichia coli, coliform bacteria, faecal Enterococci (see: Table 2). The above parameters were determined by an accredited research laboratory of the State Sanitary Inspectorate (PIS).

In all examined waters, additional analysis of the following components was performed: boron, silicon, sulphur, bromine, iodine. Two methods were used: inductively coupled plasma mass spectrometry (ICP $\mathrm{MS}$ ), and inductively coupled plasma optical emission spectrometry (ICP - OES) (Table 8). The above-mentioned samples also have fluorine content determined with ion chromatography (see: Table 8), the analysis was carried out by the accredited PIS testing laboratory. 
Chorostyński, A., Kaczmarski, M., Łach, A., Wrona M. (2019). Analysis of spring waters from Lesko in terms of their medical properties. Acta Sci. Pol., Formatio Circumiectus, 18 (3), 31-41. DOI: http://dx.doi.org/10.15576/ASP.FC/2019.18.3.31

Table 3. The content of heavy metals

\begin{tabular}{ccccccccc}
\hline METAL & Unit & $\begin{array}{c}\text { Zinc } \\
\mathrm{Zn}\end{array}$ & $\begin{array}{c}\text { Cadmium } \\
\mathrm{Cd}\end{array}$ & $\begin{array}{c}\text { Copper } \\
\mathrm{Cu}\end{array}$ & $\begin{array}{c}\text { Lead } \\
\mathrm{Pb}\end{array}$ & $\begin{array}{c}\text { Nickel } \\
\mathrm{Ni}\end{array}$ & $\begin{array}{c}\text { Chromium } \\
\mathrm{Cr}\end{array}$ & $\begin{array}{c}\text { Mercury } \\
\mathrm{Hg}\end{array}$ \\
\hline $\begin{array}{c}1,2,3,4,5 \\
\text { ASA traceability }\end{array}$ & $\mu \mathrm{g} \cdot \mathrm{dm}^{-3}$ & $<10$ & $<1$ & $<10$ & $<4$ & $<5$ & $<5$ & $<0.08$ \\
\hline $\begin{array}{c}\text { Norm according } \\
\text { to the Regulation } \\
\text { by the Minister for } \\
\text { Public Health }\end{array}$ & $\mu \mathrm{g} \cdot \mathrm{dm}^{-3}$ & 3000 & 5 & 2000 & 10 & 20 & 50 & 1 \\
\hline
\end{tabular}

Table 4. The content of microelements

\begin{tabular}{|c|c|c|c|c|c|c|}
\hline $\begin{array}{c}\begin{array}{c}\text { Element } \\
\mu \mathrm{g} \cdot \mathrm{dm}^{-3}\end{array} \\
\text { Sample }\end{array}$ & $\begin{array}{l}\mathrm{Fe}(\mathrm{og}) \\
\text { Iron }\end{array}$ & $\begin{array}{c}\text { Mn (og) } \\
\text { Manganese }\end{array}$ & $\begin{array}{c}\mathrm{Li} \\
\text { Lithium }\end{array}$ & $\begin{array}{l}\text { As }(o g) \\
\text { Arsenic }\end{array}$ & $\begin{array}{c}\text { Se (og) } \\
\text { Selenium }\end{array}$ & $\begin{array}{c}\text { Mo } \\
\text { Molybdenum }\end{array}$ \\
\hline 1 & 10 & 20 & $<100$ & $<0.3$ & $\begin{array}{c}<5<5 \\
\text { ASA ICP-MS }\end{array}$ & $<5$ ICP-MS \\
\hline 2 & 10 & 10 & $<100$ & $<0.3$ & $<5<5$ & $<5$ \\
\hline 3 & 10 & 20 & $<100$ & $<0.3$ & $<5<5$ & $<5$ \\
\hline 4 & 20 & 30 & $<100$ & $<0.3$ & not tested & not tested \\
\hline 5 & 10 & 10 & $<100$ & $<0.3$ & not tested & not tested \\
\hline $\begin{array}{l}\text { Norm according } \\
\text { to the Regulation } \\
\text { by the Minister for } \\
\text { Public Health }\end{array}$ & 200 & 50 & - & 10 & - & - \\
\hline
\end{tabular}

Table 5. The content of alkali metals and alkaline earth metals

\begin{tabular}{ccccccc}
\hline Type of metal & Unit & $\begin{array}{c}\mathrm{Na} \\
\text { Sodium }\end{array}$ & $\begin{array}{c}\mathrm{K} \\
\text { Potassium }\end{array}$ & $\begin{array}{c}\mathrm{Ca} \\
\text { Calcium }\end{array}$ & $\begin{array}{c}\mathrm{Mg} \\
\text { Magnesium }\end{array}$ & $\begin{array}{c}\text { Sum } \\
\text { of cations }\end{array}$ \\
\hline 1 & $\mathrm{mg} \cdot \mathrm{dm}^{-3}$ & 22 & 2 & 74 & 22 & 120 \\
\hline 2 & $\mathrm{mg} \cdot \mathrm{dm}^{-3}$ & 5 & 1 & 66 & 21 & 93 \\
\hline 3 & $\mathrm{mg} \cdot \mathrm{dm}^{-3}$ & 29 & 2 & 72 & 24 & 127 \\
\hline 4 & $\mathrm{mg} \cdot \mathrm{dm}^{-3}$ & 30 & 3 & 88 & 27 & 147 \\
\hline 5 & $\mathrm{mg} \cdot \mathrm{dm}^{-3}$ & 330 & 8 & 133 & 27 & 498 \\
\hline
\end{tabular}


Chorostyński, A., Kaczmarski, M., Łach, A., Wrona M. (2019). Analysis of spring waters from Lesko in terms of their medical properties. Acta Sci. Pol., Formatio Circumiectus, 18 (3), 31-41. DOI: http://dx.doi.org/10.15576/ASP.FC/2019.18.3.31

Table 6. Content of anions and carbon dioxide

\begin{tabular}{|c|c|c|c|c|c|c|c|}
\hline $\begin{array}{c}\begin{array}{c}\text { ANION } \\
\mathrm{mg} \cdot \mathrm{dm}^{-3}\end{array} \\
\text { Sample }\end{array}$ & $\begin{array}{c}\mathrm{CO}_{2} \\
\text { carbon } \\
\text { dioxide }\end{array}$ & $\begin{array}{c}\mathrm{HCO}_{3}^{-} \\
\text {bicarbonates }\end{array}$ & $\begin{array}{c}\mathrm{Cl}^{-} \\
\text {chlorides }\end{array}$ & $\begin{array}{c}\mathrm{SO}_{4}^{2-} \\
\text { sulphates }\end{array}$ & $\begin{array}{l}\text { Sum of } \\
\text { anions }\end{array}$ & $\begin{array}{l}\text { Mineralisation } \\
\text { (anions+cations) }\end{array}$ & $\begin{array}{c}\text { Type of } \\
\text { mineralisation }\end{array}$ \\
\hline 1 & 103 & 366 & 13 & 9 & 388 & 508 & $\begin{array}{l}\text { moderately } \\
\text { mineralised }\end{array}$ \\
\hline 2 & 115 & 311 & 5 & 30 & 346 & 439 & $\begin{array}{c}\text { low } \\
\text { mineralised }\end{array}$ \\
\hline 3 & 98 & 327 & 11 & 14 & 351 & 478 & $\begin{array}{c}\text { low } \\
\text { mineralised }\end{array}$ \\
\hline 4 & 26 & 329 & 23 & 42 & 394 & 541 & $\begin{array}{l}\text { moderately } \\
\text { mineralised }\end{array}$ \\
\hline 5 & 127 & 752 & 395 & 4 & 1151 & 1649 & $\begin{array}{l}\text { highly } \\
\text { mineralised }\end{array}$ \\
\hline
\end{tabular}

Table 7. Zawartość siarki, siarkowodoru, siarczków, siarczanów VI

\begin{tabular}{|c|c|c|c|c|c|c|c|c|c|c|c|}
\hline \multirow{3}{*}{$\begin{array}{l}\text { PARAMETER } \\
\text { SAMPLE }\end{array}$} & \multirow{3}{*}{$\begin{array}{l}\mathrm{pH} \\
\mathrm{pH}\end{array}$} & \multirow{3}{*}{ 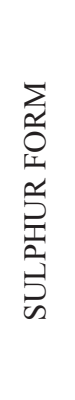 } & \multicolumn{2}{|c|}{$\begin{array}{l}\text { SULPHIDES } \\
\mathrm{mg} \cdot \mathrm{dm}^{-3}\end{array}$} & \multirow{3}{*}{ 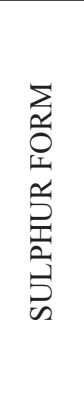 } & \multirow{3}{*}{ 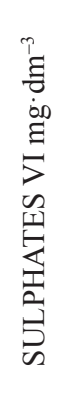 } & \multicolumn{4}{|c|}{$\begin{array}{l}\text { SULPHUR CONCENTRATION mg } \\
\qquad \mathrm{S} \cdot \mathrm{dm}^{-3}\end{array}$} & \multirow{3}{*}{ 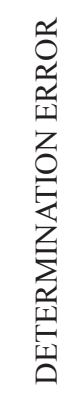 } \\
\hline & & & \multirow[t]{2}{*}{$\begin{array}{l}5 \\
5 \\
5 \\
\text { 夏 }\end{array}$} & \multirow{2}{*}{ 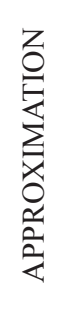 } & & & $\begin{array}{l}\frac{0}{0} \\
\frac{0}{3} \\
\frac{0}{\bar{n}}\end{array}$ & 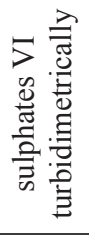 & 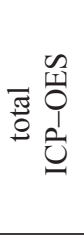 & 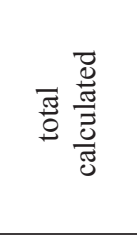 & \\
\hline & & & & & & & 1 & 2 & 3 & $4=1+2$ & \\
\hline 1 & 7.70 & $\begin{array}{l}\mathrm{H}_{2} \mathrm{~S} \\
\mathrm{HS}^{-}\end{array}$ & 1.920 & 1.9 & $\mathrm{SO}_{4}^{2-}$ & 9.0 & 1.9 & 3.0 & 4.6 & 4.9 & $6.5 \%$ \\
\hline 2 & 7.30 & $\begin{array}{l}\mathrm{H}_{2} \mathrm{~S} \\
\mathrm{HS}^{-}\end{array}$ & 0.097 & 0.1 & $\mathrm{SO}_{4}^{2-}$ & 30.0 & 0.1 & 10.0 & 10.4 & 10.1 & $2.9 \%$ \\
\hline 3 & 7.60 & $\begin{array}{l}\mathrm{H}_{2} \mathrm{~S} \\
\mathrm{HS}^{-} \\
\end{array}$ & 0.830 & 0.8 & $\mathrm{SO}_{4}^{2-}$ & 14.0 & 0.8 & 4.7 & 5.1 & 5.5 & $7.8 \%$ \\
\hline 5 & 7.20 & $\begin{array}{l}\mathrm{H}_{2} \mathrm{~S} \\
\mathrm{HS}^{-}\end{array}$ & 1.400 & 1.4 & $\mathrm{SO}_{4}^{2-}$ & 4.0 & 1.4 & 1.3 & 2.9 & 2.7 & $6.9 \%$ \\
\hline
\end{tabular}

Table 8. Contents of non-metals

\begin{tabular}{ccccccccc}
\hline $\begin{array}{c}\text { Non-metal } \\
\mathrm{mg} \cdot \mathrm{dm}^{-3}\end{array}$ & Boron B & $\begin{array}{c}\mathrm{HBO}_{2} \\
\text { Metaboric acid } \\
\text { (calculated) }\end{array}$ & $\begin{array}{c}\text { Silicon } \\
\mathrm{Si}\end{array}$ & $\begin{array}{c}\mathrm{H}_{2} \mathrm{SiO}_{3} \\
\text { Orthosilicic } \\
\text { acid } \\
\text { (calculated) }\end{array}$ & $\begin{array}{c}\mathrm{S} \\
\text { Sulphur }\end{array}$ & $\begin{array}{c}\mathrm{F} \\
\text { Fluorine }\end{array}$ & $\begin{array}{c}\mathrm{Br} \\
\text { Bromine }\end{array}$ & $\begin{array}{c}\mathrm{I} \\
\text { Iodine }\end{array}$ \\
\hline 1 & 0.135 & 0.547 & 6.7 & 18.6 & 4.6 & 0.20 & $<0.1$ & 0.25 \\
\hline 2 & 0.084 & 0.340 & 11.3 & 31.4 & 10.4 & 0.11 & $<0.1$ & 0.18 \\
\hline 3 & 0.058 & 0.235 & 10.7 & 29.7 & 5.1 & 0.17 & $<0.1$ & 0.22 \\
\hline 4 & 0.027 & 0.109 & 9.2 & 25.5 & 14.0 & 0.10 & $<0.1$ & 0.10 \\
\hline 5 & 5.762 & 23.350 & 8.2 & 22.8 & 2.9 & 0.19 & 1.4 & 0.40 \\
\hline
\end{tabular}


The method of atomic absorption spectrometry (ASA) was also used to determine the content of selenium in waters $(1,2,3)$ (see: Table 4$)$. The selenium determination was repeated (checked) with inductively coupled plasma mass spectrometry (ICP-MS). In an environmental research laboratory, the ICP - MS method was used to determine the concentration of a trace element (a micronutrient) molybdenum (a bio element) in the same waters.

All physicochemical measurements such as: $\mathrm{pH}$, ORP, conductivity, temperature were made "at the source" using portable instruments (Łach, 2011) by the authors of the work. Also, all ASA analyses (Na, $\mathrm{K}, \mathrm{Mg}, \mathrm{Ca}, \mathrm{Mn}, \mathrm{Fe}, \mathrm{Zn}, \mathrm{Cu}, \mathrm{Pb}, \mathrm{Cd}, \mathrm{Ni}, \mathrm{Cr}, \mathrm{Hg}, \mathrm{As}$, $\mathrm{Se})$ and some ICP analyses - MS i ICP - OES (B, Si, $\mathrm{I}, \mathrm{Br}, \mathrm{S})$ were performed by the authors of the work.

Knowing the results of the determination of sulphides, sulphates (VI), and the total amount of sulphur, the relative error of sulphur determination was calculated. In Table 7 the content of various forms of sulphur was balanced and converted to pure sulphur. The table includes three different test methods for the determination of sulphides: thiomercurimetry, photometry (instrumental analysis - TEST Macherey-Nagel), iodometry, and the instrumental method for the determination of sulphates (VI) - turbidimetry and determination of pure sulphur - inductively coupled plasma excitation emission spectrometry (ICP-OES). Comparison of the determination of various forms of sulphur using 5 methods (including three instrumental ones) with a maximum error of $7.8 \%$ is considered satisfactory (Chorostyński et al., 2018).

\section{RESULTS AND CONCLUSIONS}

The results were included in Tables $1-8$. There was a slight variation between the results of the determination of the same parameters of individual analysed spring waters at different times of the year. The smallest standard percentage deviation - \% RSD (Relative Standard Deviations) was $2-3 \%$ and concerned the measurement of $\mathrm{pH}$ value. The highest $\% \mathrm{RSD}$ was $7-8 \%$ and was characteristic for determinations made with titration methods and ICP-OES method. The recorded values of percentage standard deviations for individual parameters of the same spring water did not exceed the coefficients of variation of the test methods used for their determination. The results of physicochemical measurements of sulphide water from Lesko (1) were taken from the article (Chorostyński et al., 2018).

The bivalent sulphur content in the water sample (1) from Lesko, $\left(1.9 \mathrm{mg} \cdot \mathrm{dm}^{-3}\right)$ allows to state that it is sulphide water with a bivalent sulphur content above $1 \mathrm{mg} \cdot \mathrm{dm}^{-3}$, therefore it meets the criterion to be classified as a healing water. Pharmacodynamic coefficients are the minimum contents of selected chemical components (so-called specific components) or the minimum value of physical properties of water, causing their therapeutic effect (Regulation, 2006; Michalski, 2006). Considering the coefficients, it can be shown that water (1) is "specific healing sulphide water". Also, healing water (5) with a divalent sulphur content of $1.4 \mathrm{mg} \cdot \mathrm{dm}^{-3}\left(\mathrm{H}_{2} \mathrm{~S}\right)$ is this kind of water. In the $\mathrm{pH}$ range of 5-7, which is the most commonly found in natural waters, both gaseous $\mathrm{H}_{2} \mathrm{~S}$ and hydrosulphide ion (HS-) may be present (Kowal and Świderska-Bróż, 2000). At pH > 7, which happens in the waters we study, the equilibrium shifts towards the hydrosulphide ion $\left(\mathrm{HS}^{-}\right)$(see: Table 7).

The oxidation-reduction potential (ORP), also known as the redox potential of any fluid, depends on the activity of electrons (Suslow 2004). Sulphide waters $(1,3)$ from Lesko have a very low redox potential (see: Table 2) which results from, among others, reduction properties of sulphides (Chorostyński and in., 2018). The more negative the redox potential (expressed in millivolts), the greater the water's reducing (anti-oxidative) properties (Hanaoka et al., 2004). Negative ORP water can have a positive effect on our health because, having reducing properties, it is an antioxidant that causes "neutralisation" of free radicals (Ignacio et al., 2012).

The prolonged state of the disturbed acid-base balance leads to adverse health consequences, the clinical symptoms of which are acidosis (a condition in which the acid-base balance is shifted towards lower $\mathrm{pH}$ values), fatigue, lack of appetite, migraine, drowsiness, increased urinary excretion of minerals $(\mathrm{Na}, \mathrm{Ca}, \mathrm{Mg})$ leading to kidney stones, increased blood pressure (Gertig and Przysławski, 2006). All sulphide waters are slightly alkaline e.g. water $(1,2,3)$ (see: Table 2), therefore, it is advisable to drink them in case of disturbed acid-base balance (acidosis, excess stomach 
Chorostyński, A., Kaczmarski, M., Łach, A., Wrona M. (2019). Analysis of spring waters from Lesko in terms of their medical properties. Acta Sci. Pol., Formatio Circumiectus, 18 (3), 31-41. DOI: http://dx.doi.org/10.15576/ASP.FC/2019.18.3.31

Table 9. Sulphide waters of Carpathian province (selected hydrogeochemical data) (Paczyński and Sadurski, 2007)

\begin{tabular}{cccccc}
\hline Town/Place & $\begin{array}{c}\text { Number of } \\
\text { springs }\end{array}$ & $\begin{array}{c}\text { Resources } \\
\mathrm{m}^{3} \cdot \mathrm{h}^{-1}\end{array}$ & $\begin{array}{c}\mathrm{H}_{2} \mathrm{~S} \\
\mathrm{mg} \cdot \mathrm{dm}^{-3}\end{array}$ & $\begin{array}{c}\text { Mineralisation } \\
\mathrm{g} \cdot \mathrm{dm}^{-3}\end{array}$ & Type of water \\
\hline Krzeszowice & 1 & 6.61 & $3.7-7.8$ & $2.1-3.1$ & $\mathrm{SO}_{4}-\mathrm{Ca}-\mathrm{Mg}, \mathrm{H}_{2} \mathrm{~S}$ \\
\hline Hyżne - Nieborów & 4 & 1.3 & $3.7-15.6$ & $1.4-3.6$ & $(\mathrm{Cl})-\left(\mathrm{HCO}_{3}\right)-\mathrm{Na}-\mathrm{Ca}, \mathrm{H}_{2} \mathrm{~S}, \mathrm{~B}$ \\
\hline Lesko & 4 & 0.2 & $1.0-2.5$ & $0.4-0.5$ & $\mathrm{HCO}_{3}-\mathrm{Ca}-(\mathrm{Mg}), \mathrm{H}_{2} \mathrm{~S}$ \\
\hline Wapienne & 2 & 2.92 & $0.5-10.5$ & $0.2-0.53$ & $\mathrm{HCO}_{3}-\mathrm{Ca}-\mathrm{Mg}-(\mathrm{Na}), \mathrm{H}_{2} \mathrm{~S}$ \\
\hline
\end{tabular}

acid). Water alkalinity may result not only from the presence of alkali metals (sodium, potassium, calcium, magnesium). If the water contains sulphides (hydrosulphides) of alkali metals, they dissociate in the aqueous environment. In turn, ions hydrolyse, resulting in the formation of hydrogen sulphide and hydrox$\mathrm{yl}$ ions $\mathrm{HS}^{-}+\mathrm{H}_{2} \mathrm{O}=\mathrm{H}_{2} \mathrm{~S}+\mathrm{OH}^{-}$, which give the water an alkaline reaction (Chorostyński et al., 2018).

Sulphide waters from Lesko $(1,2,3)$ were bacteriologically tested (Escherichia Coli, coliform bacteria, faecal enterococci), all were drinkable (no pathogenic bacteria) (see: Table 2).

In the examined waters, no heavy metals, arsenic or mercury were detected. It has been shown that in spring waters, mercury and arsenic are not present even in trace amounts, which makes the water fit for consumption (Regulation, 2017; Michalski, 2007).

Water from Lesko consists iron and manganese in trace amounts. Thanks to this, the extracted water is clear, does not precipitate sediments of $\mathrm{Fe}(\mathrm{OH})_{3}$ (brown, colloidal sediment) or $\mathrm{MnO}_{2}$ (manganese(IV) oxide - brown sediment). The maximum value of manganese concentration in drinking water allowed by the Minister of Health (Regulation, 2017) may not exceed $50 \mu \mathrm{g} \cdot \mathrm{dm}^{-3}$, while the iron concentration $200 \mu \mathrm{g} \cdot \mathrm{dm}^{-3}$ (see: Table 4). Manganese deficiency is mainly expressed in the form of impaired motor coordination, osteoarticular damage and osteoporosis (Zawadzki et al., 2008). Anaemia is a classic symptom of iron deficiency in the body that is confirmed by a decrease in haemoglobin below normal for a given age and sex (Gertig and Przysławski, 2006).

Mineral water spring in Lesko (4) does not contain sulphides but has a relatively elevated content of sodium, potassium, calcium and magnesium (in regard of sulphide waters of Lesko). Determination of the con- centration of these elements and the concentration of anions in all waters allowed the calculation of mineralisation (sum of solid components) (see: Table 6). Water $(1,4)$ turned out to be medium mineralised, water $(2,3)$ was low mineralised, and comparative water (5) was highly mineralised (Regulation, 2003).

The content of boron $\left(\mathrm{HBO}_{2}\right)$, silicon $\left(\mathrm{H}_{2} \mathrm{SiO}_{3}\right)$, iodine and fluorine was determined in the examined waters (Table 8). The quantities of elements were compared with pharmacodynamic coefficients (Regulation, 2006; Michalski, 2006) and there is no element present in a quantity that allows naming the water (except sulphides) as a "specific water".

The capacity of $0.2 \mathrm{~m}^{3} \cdot \mathrm{h}^{-1}$ (Paczyński and Sadurski 2007) of sulphide springs in Lesko (Table 9) is low in comparison with other sulphide springs (Krzeszowice, Hyżne-Nieborów, Wapienne). The Lesko water (bicarbonate-calcium-magnesium, sulphide type) $\mathrm{HCO}_{3}-\mathrm{Ca}-(\mathrm{Mg}), \mathrm{H}_{2} \mathrm{~S}$ is the closest to sulphide waters in Wapienne (Chowaniec et al., 2013; Chorostyński et al., 2018).

\section{CONCLUSIONS}

1. Spring water from Lesko (1) with a hydrogen sulphide concentration of $1.9 \mathrm{mg} \cdot \mathrm{dm}^{-3}$ is a "specific healing sulphide" water.

2. Sulphide waters are slightly alkaline and their alkalinity results from the hydrolysis of sulphide ions.

3. Sulphide waters from Lesko have low oxidation-reduction potential (ORP) (they have reducing properties), i.e. they are antioxidants.

4. No heavy metals, including mercury and arsenic, were detected in all waters. The lack of trace amounts of these elements makes these waters fit for consumption. It is significant since there are 
underground waters containing arsenic (Rabe, Bystre) south-east of Lesko.

5. Sulphide waters were bacteriologically tested, no pathogenic bacteria were detected.

6. The Lesko sulphide spring $\left(1.9 \mathrm{mg} \cdot \mathrm{dm}^{-3} \mathrm{H}_{2} \mathrm{~S}\right)$ has a higher concentration of hydrogen sulphide than the Jan sulphide spring in Rymanów Zdrój. However, water from Rymanów has higher specific conductivity and mineralisation (highly mineralised water).

7. Considering the conclusions, it should be stated that the springs, despite their low efficiency, are suitable for use as healing waters.

\section{REFERENCES}

ATSDR (Agency for Toxic Substances and Disease Registry). (2007). Toxicological Profile for Arsenic. Washington, DC: US Department of Health and Human Services.

Chorostyński, A., Łach, A., Pasztyła G. (2016). Minerały, metale ciężkie, medycyna, analiza wody z Rabe. Cz. II. Laboratoria, Aparatura, Badania, 21(1), 44-52.

Chorostyński, A., Łach, A., Pasztyła, G. (2018). Parametry fizykochemiczne i bakteriologia odkrytych wód mineralnych i siarczkowych w okolicach Sanoka i Leska, oraz możliwości leczniczego wykorzystania tych wód. Acta Scientarium Polonorum. Seria Farmatio Circumiectus. Kraków. 17(1), 113-126.

Chowaniec, J., Hajduga, M., Porwisz, B., Radwan, J. (2013). Najmniejsze i jedyne uzdrowisko karpackie z wodami siarczkowymi w miejscowości Wapienne koło Gorlic. Biuletyn Państwowego Instytutu Geologicznego. 456, $75-80$

Dobrzyński, D., Stępień, M. (2009). Ocena dystrybucji arsenu w wybranych wodach leczniczych Sudetów na podstawie filtracji membranowej i modelowania specjacyjnego. Biuletyn Państwowego Instytutu Geologicznego. 436, 95-102.

Gertig, H., Przysławski, J. (2006). Bromatologia. Zarys nauki o żywności i żywieniu. Warszawa: Wydawnictwo Lekarskie PZWL, 182-183.

Hanaoka, K., Sun, D., Lawrence, R., Kamitani, Y., Fernandes, G. (2004). The mechanism of the enhanced antioxidant effects against superoxide anion radicals of reduced water produced by electrolysis. Biophysical chemistry. 107, 1, 71-82.

Ignacio, R. M. C., Joo, K-B., Lee, K-J. (2012). Clinical Effect and Mechanism of Alkaline Reduced Water. Journal of Food and Drug Analysis, 20, 1, 394-397.
Jaworski, A. (1979). Rtęć, arsen i pierwiastki grupy żelaza w utworach fliszowych kredy górnej i paleogenu Łuski Bystrego koło Baligrodu. Rocz. Polskiego Towarzystwa Geologicznego. 49(3/4), 379-394.

Jaworski, M., Uliasz, A. (2006). Źródła i zdroje rymanowskie. Stowarzyszenie Przyjaciół Rymanowa Zdroju. ROCZNIK RYMANOWA ZDROJU. Tom IX.

Kamieński, M. (1937). O minerałach arsenowych z fliszu karpackiego okolicy Leska. Arch. Mineral. Warszawa. $13,1-8$.

Kowal, A. L., Świderska-Bróż, M. (2000). Oczyszczanie wody. Warszawa-Wrocław: Wydawnictwo Naukowe PWN, 37-38.

Kozak, E. (2016). Źródła wód mineralnych i zwykłych w województwie podkarpackim. Rzeszów : Wojewódzki Inspektorat Ochrony Środowiska.

Łach, A. (2005). Szukamy wód uzdrowiskowych na Podkarpaciu. Bioskop. Warszawa: Wydawnictwo Malamut, (1), 20-25.

Łach, A. (2011). Demineralizacja wody naturalnej za pomocą wymieniaczy jonowych. Towarzystwo Chemii i Inżynierii Ekologicznej. Chemia. Dydaktyka. Ekologia. Metrologia. Opole. 16(1), 97-101.

Łach, A., Pasztyła, G. (2013). Unikalne wody litowo-arsenowe w Rabe. Laboratoria, Aparatura, Badania, 18(6), 6-10.

Michalski, R. (2006). Wody mineralne - pić albo nie pić? Laboratorium. Wydawnictwo Elamed. Katowice. (11), 36-38

Michalski, R. (2007). Wybrane parametry fizykochemiczne wód i ścieków w przepisach polskich i międzynarodowych cz. I - Kryteria oceny jakości wód i ścieków. Laboratorium. Wydawnictwo Elamed. Katowice. (4), 14-18.

Minczewski, J., Marczenko, Z. (2011). Chemia analityczna. Analiza ilościowa. Warszawa: PWN. T. 2.

National Research Council. (2001). Arsenic in Drinking Water: 2001 Update. Washington, DC: The National Academies Press.

Paczyński, B., Sadurski, A. (2007). Hydrogeologia regionalna Polski. T. II. Wody mineralne, lecznicze i termalne oraz kopalniane. Warszawa: Państwowy Instytut Geologiczny.

Paluch, J. (1973). Mikrobiologia wód. Warszawa: Państwowe Wydawnictwo Naukowe, 96.

Rajchel, L. (2000). Źródła wód siarczkowych w Karpatach Polskich. Geologia AGH. 26(3): 309-373.

Rajchel, L., Marszałek, M. Rajchel, J. (2000). Osady źródeł siarczkowych Karpat i zapadliska przedkarpackiego. Prz. Geol. 48(12), 1174-1180.

Rajchel, L. Rajchel, J., Szaran, J. Hałas, S. (2002). Sulphur isotopic composition of $\mathrm{H}_{2} \mathrm{~S}$ and $\mathrm{SO}_{4}^{2-}$ from mineral 
springs in the Polish Carpathians. Isotopes Environ. Health Stud. 38(4), 277-284.

Rajchel, L., Zuber, A., Duliński, M., Rajchel, J. (2005). Składy izotopowe i chemiczne oraz wieki wody ze źródeł siarczkowych w polskich Karpatach. In: Współczesne problemy hydrogeologii (red. A. Sadurski, A., Krawiec) UMK. Toruń. 12, 583-588.

Rozporządzenie Ministra Zdrowia z dnia 18 kwietnia 2003 r. w sprawie szczególnych warunków sanitarnych oraz wymagań w zakresie przestrzegania zasad higieny $\mathrm{w}$ procesie produkcji lub w obrocie naturalnymi wodami mineralnymi i naturalnymi wodami źródlanymi Dz. U. z 2003 r. Nr 89, poz. 842.

Rozporządzenie Ministra Zdrowia z dnia 13 kwietnia 2006 r. w sprawie zakresu badań niezbędnych do ustalenia właściwości leczniczych naturalnych surowców leczniczych i właściwości leczniczych klimatu, kryteriów ich oceny oraz wzoru świadectwa potwierdzającego te właściwości. Dz. U. z 2006 r. Nr 80, poz. 565.
Rozporządzenie Ministra Zdrowia z dnia 7 grudnia 2017 r. w sprawie jakości wody przeznaczonej do spożycia przez ludzi. Dz. U. z 2017 poz. 2294.

Suslow, T. V. (2004). Oxidation-Reduction Potential for Water Disinfection Monitoring, Control and Documentation. University of California.

Tchórzewska-Cieślak, B., Rak, J. (2005). Charakterystyka wód mineralnych uzdrowisk Podkarpacia. II Konferencja N-T „Błękitny San“ „Ochrona środowiska, walory przyrodnicze i rozwój turystyki w dolinie Sanu”, Związek Gmin Turystycznych Pogórza Dynowskiego. Dynów 21-23.04.05, 107-120.

Tchórzewska-Cieślak, B., Rak, J. (2006). Wody mineralne i lecznicze w uzdrowiskach Podkarpacia. Wydawnictwo Sigma NOT. Gaz, Woda i Technika Sanitarna. 11, 57-59.

Zawadzki, M., Gać, P., Poręba, R., Andrzejak, R. (2008). Zmiany w układzie sercowo-naczyniowym zwierząt poddawanym intoksykacji związkami manganu. Medycyna pracy. 59(5), 387-393.

\section{ANALIZA WÓD ŹRÓDLANYCH Z LESKA W ASPEKCIE ICH LECZNICZYCH WŁAŚCIWOŚCI}

\section{ABSTRAKT}

\section{Cel pracy}

Celem pracy było wykazanie właściwości leczniczych wód źródlanych z Leska na podstawie ich analizy fizykochemicznej.

\section{Materiat i metody}

W Lesku znajdują się trzy aktywne źródła siarczkowe, oraz jedno mineralne. W próbkach wody z Leska $(1,2,3)$ oznaczono siarczki i siarkowodór (siarka dwuwartościowa). Stężenie siarczków i siarkowodoru w źródłach, określono metodami: jodometryczną, fotometryczną i tiomercurymetryczną. We wszystkich próbkach wody sprawdzono obecność 7 metali ciężkich metodą ASA. We wszystkich badanych wodach dodatkowo przeprowadzono analizę ilościową takich składników jak: kwas metaborowy, kwas ortokrzemowy, siarka, brom, jod dwoma metodami: ICP-MS oraz ICP-OES. Oznaczono również zawartość fluoru metodą chromatografii jonowej.

\section{Wyniki i wnioski}

Wszystkie wody z Leska oprócz wody mineralnej zawierają siarczki. We wszystkich wodach źródlanych nie wykryto metali ciężkich w tym rtęci oraz arsenu. Nie stwierdzono obecności litu oraz większej ilości żelaza i manganu. W wodach $(1,2,3)$ nie wykryto obecności selenu i molibdenu. W badanych wodach $(1,2,3,4)$ stwierdzono obecność kwasu metaborowego, kwasu ortokrzemowego, fluoru i jodków.

Słowa kluczowe: ICP-OES, balneologia, Lesko, źródła siarczkowe, ORP 